\title{
The Effect of Microwave-Assisted Alkali and Xanthomonas $t$ ranslucens ICBB 9762 for Rice Straw Pretreatment on Electricity Generation of Microbial Fuel Cell Inoculated by Staphylococcus saprophyticus ICBB 9554
}

\author{
Nur Syafira Khoirunnisa ${ }^{1}$, Syaiful Anwar ${ }^{2}$ and Dwi Andreas Santosa, ${ }^{2,3}$ \\ ${ }^{1}$ Study Program of Soil Sciences, Graduate Schools, IPB University, West Java 16680, Indonesia \\ ${ }^{2}$ Department of Soil Science and Land Resource, Faculty of Agriculture, IPB University, \\ West Java 16680, Indonesia \\ ${ }^{3}$ Biotechnology Center, Research and Community Empowerment Institute, IPB University, \\ West Java 16680, Indonesia
}

("Corresponding author's e-mail: dsantosa@indo.net.id)

Received: 11 February 2021, Revised: 1 May 2021, Accepted: 18 May 2021

\begin{abstract}
Rice straw can be utilized as an organic substrate in Microbial Fuel Cell (MFC) to generate electricity by microbes as a biocatalyst. This research was aimed to observe the effect of Xanthomonas translucens ICBB 9762 inoculation pretreatment on microwave-assisted alkali treated rice straw on the lignocellulosic structure change of rice straw and to observe the performance of MFC system fed by treated rice straw. The stages of research included: (1) pretreatment of rice straw through microwaveassisted alkali and Xanthomonas translucens ICBB 9762 inoculation, (2) observation of MFC performance including electrical voltage; electrical current; power density; and Coulombic efficiency, and (3) anolite analysis including COD removal, $\mathrm{pH}$ and $\mathrm{Eh}$. The result showed that rice straw was successfully decomposed by inoculation of Xanthomonas translucens ICBB 9762 on microwave-assisted alkali pretreatment which the highest cellulose yield about $29.36 \%$. Treated rice straw produced better performance than rice straw without pretreatment which the best performance resulted by the combination of Xanthomonas translucens ICBB 9762 inoculation and microwave-assisted alkali pretreatment which produce electrical voltage, electrical current, and power density value of $337.90 \mathrm{mV}, 0.39 \mathrm{~mA}$, and 26.20 $\mathrm{mW} / \mathrm{m}^{2}$, respectively. The utilization of solid substrate such as rice straw need more attention due to there was COD enhancement while in COD reduction reach COD removal efficiency and coulombic efficiency ranged $5.15-54.08 \%$ and $0.25-7.83 \%$, respectively.
\end{abstract}

Keywords: Cellulolytic bacteria, Degradation, Efficiency, Electricity, Performance

\section{Introduction}

Microbial Fuel Cell (MFC) is bioelectrochemical systems which directly convert chemical energy from an organic substrate to electrical energy through redox reaction [1]. MFC typically consist of anode and cathode compartment separated by cationic membrane called Proton Exchange Membrane (PEM) [2]. Active microbes act as biocatalisator for electrode reactions to oxidize organic or inorganic matter [3]. Oxidation of organic substrates produces electrons and proton. The electrons are transferred to the anode by 3 mechanisms of electron transfer, i.e. based on direct contact by outer membrane cytochromes, utilize excreted mediators (also known as shuttles), and synthesize appendages called nanowires [4]. Then electrons flow to the cathode linked by a conductive material as electrical circuit and protons cross the membrane [5].

This research is focused to study of organic substrate utilization which rice straw is selected and its manipulation effect for MFC system performance. Substrate is important for any biological process as carbon and energy source. We need to consider efficiency and economic viability by looking the chemical composition and the concentrations of the components that can be converted into products or fuels. A great variety of substrates can be used in MFCs ranging from simple pure compounds such as glucose to complex mixtures of organic matter such as wastewater [6]. Cellulose and lignocellulose are complex 
substrates that can be used in MFC. Some researchers utilize cellulolytic bacteria to degrade cellulose for MFC [7,8]. Lignocellulose such as straw also have been studied as substrate in MFC. Some studies reported wheat straw without pretreatment [9,10], wheat straw with hydrothermal pretreatment [11], wheat straw as catholite degraded by white rot fungi [12] and rice straw with chemical pretreatment using acid, alkali and hydrogen peroxide compounds [13].

Plant biomass such as rice straw is the most abundant renewable resource for bioenergy because a high cellulose content. Cellulose is crystalline and encapsulated by lignin and hemicellulose causes hydrophobic properties so it needs to be deconstructed to simpler chemical forms before further processing [14]. The pretreatment process of lignocellulose facilitate to open the structure of lignocellulose thus cellulose becomes more accessible by enzymes that break down polysaccharide polymers into monomer forms [15]. Some pretreatments that have been studied are ultrasound pretreatment [16,17], ligninolytic fungi or bacteria [18,19], alkaline or acid pretreatment [20], microwaveassisted alkalization and acid oxidation [21,22]. Microwave-assisted alkali pretreatment is 1 of alternative to break down lignocellulose structure. This treatment has some advantages such as reduced process energy requirements, selective processing, and precise control. In addition, the heating process is volumetric and fast because heat is generated internally through direct interaction between the electromagnetic field and the components of the heated material [23].

The delignified cellulose polymers need to be hydrolyzed into glucose monomers. Cellulose depolymerization can be utilized by cellulose degrading bacteria which is synthetize cellulase enzyme. The cellulase enzyme breaks the $\beta-1,4$ bond in the cellulose chain [24]. This enzyme consists of exocellulase or exobiohydrolase, endocellulase or endo $\beta$-1,4-glucanase and $\beta$-1,4-glucosidase or selobiase [25]. Some bacteria that are reported as cellulolytic bacteria such as the genera Clostridium, Cellulomonas, Cellulosimicrobium, Thermomonospora, Bacillus, Ruminococcus, Erwinia, Bacteriodes, Acetovibrio, Streptomyces, Microbispora, Fibrobacter, and Paenibacillus. [26]This research utilizes Xanthomonas translucens ICBB 9762 from previous study [27] as cellulose degrading bacteria for rice straw pretreatment.

\section{Materials and methods}

\section{Rice straw biomass, isolates and culture media}

Rice straw was obtained from farmers in Bogor, Indonesia, as residue from the harvest that was Inpari 32 variety type. The rice straw was dried under sunlight and then oven at $70{ }^{\circ} \mathrm{C}$ for $4 \mathrm{~h}$, the milled (particle size $100 \mathrm{mesh}$ ) and store in an airtight container for further use. [26]

This research utilized 2 bacterial isolates, cellulolytic bacteria, Xanthomonas translucens ICBB 9762 isolated from decomposed rice straw from rice soil in Bogor, Indonesia [27], and exoelectrogen bacteria, Staphylococcus saprophyticus ICBB 9554 isolated from the rice soil ecosystem in Banten, Indonesia and have been studied for the MFC system before. The Xanthomonas translucens ICBB 9762 was maintained on $\mathrm{CMC}$ (Carboxymethyl Cellulose) agar (in 1 liter of media containing: $1 \mathrm{~g} \mathrm{KH}_{2} \mathrm{PO}_{4}, 0.5$ $\mathrm{g} \mathrm{K}_{2} \mathrm{SO}_{4}, 0.5 \mathrm{~g} \mathrm{NaCl}, 0.01 \mathrm{~g} \mathrm{FeSO}_{4}, 0.01 \mathrm{~g} \mathrm{MnSO}_{4}, 1 \mathrm{~g}\left(\mathrm{NH}_{4}\right) \mathrm{NO}_{3}, 10 \mathrm{~g} \mathrm{CMC}$ powder, and $20 \mathrm{~g}$ agar) whereas Staphylococcus saprophyticus ICBB 9554 was maintained on thioglycollate agar (in 1 liter of media containing: $30 \mathrm{~g} \mathrm{Merck}^{\circledR}$ thioglycolate broth and $20 \mathrm{~g}$ agar).

\section{Experimental design}

The rice straw powder was pre-treated by microwave-microwave-assisted alkali and inoculation of Xanthomonas translucens ICBB 9762 that were combined with the following combination:

$\mathrm{A}=$ rice straw with microwave-assisted alkali and Xanthomonas translucens ICBB 9762 inoculation pretreatment

$\mathrm{B}=$ rice straw with microwave-assisted alkali pretreatment

$\mathrm{C}=$ rice straw with Xanthomonas translucens ICBB 9762 inoculation pretreatment

$\mathrm{D}=$ rice straw without pretreatment

Each pre-treated rice straw added into the MFC system experiment that designed by factorial completely randomized design consisting of 3 factors for 4 treatment sets. The first factor is the concentration of rice straw as a substrate which consists of 3 levels, i.e. $0.2 \%(\mathrm{w} / \mathrm{v}) ; 0.4 \%$ (w/v) and 0.6 $\%(\mathrm{w} / \mathrm{v})$ that were coded by "2", "4", and "6", respectively. The second factor is the rice straw sterilization which consists of 2 levels, i.e. sterilized and non-sterilized that were coded by "S" and "NS". The third factor is the inoculation of exoelectrogen bacteria, Staphylococcus saprophyticus ICBB 9554, which consists of 2 levels, i.e. by addition and without addition that were coded by "(+)" and "(-)". Each treatment was repeated 3 times. 


\section{Microwave-assisted alkali pretreatment}

This pretreatment method followed the procedure from [28] by taking 100 grams of rice straw powder and added into $1,000 \mathrm{~mL}$ distilled water and added $150 \mathrm{~mL}$ of $2 \% \mathrm{NaOH}$. Then it was heated and stirred with a stirer for $2.5 \mathrm{~h}$ at $80^{\circ} \mathrm{C}$. The solution was filtered to separate the insoluble solid fiber from the soluble fraction. The insoluble solid fiber was washed with boiled water until neutral $\mathrm{pH}$. The insoluble solid rice straw fiber was irradiated using a microwave with $70 \%$ power for 40 min. The levels of lignin, cellulose, and hemicellulose after microwave-alkaline pretreatment were calculated following the AOAC procedure (1998).

\section{Xanthomonas translucens ICBB 9762 Inoculation Pretreatment}

Cellulolytic bacteria, Xanthomonas translucens ICBB 9762, need to be grown in an amount sufficient to degrade cellulose. Two loops of Xanthomonas translucens ICBB 9762 were inoculated into $50 \mathrm{~mL}$ Nutrrient Broth. The culture bacteria was incubated for $48-72 \mathrm{~h}$ at ambient temperature. A total of $75 \mathrm{mlLof}$ culture bacteria was inoculated into $50 \mathrm{~g}$ of dry rice straw (water content due to the addition of culture ranged $150 \%$ ). The mixture of rice straw and culture bacteria was incubated at room temperature for 14 days. After the incubation period, a series of tests were performed and compared between after incubation and the initial data before incubation.

\section{Configuration and operation of microbial fuel cells (MFCs)}

Design of MFC system in this study was done as described [27] The MFC chamber was a dualchamber design that was assembled by acrylic material with a size of $6 \times 6 \times 7.5 \mathrm{~cm}^{3}$ on the inside and the capacity was around $250 \mathrm{~mL}$ in each anode and cathode chamber. The anode and cathode chamber were separated by Nafion $117^{\circledR}$ Proton Exchange Membrane (PEM) (Lyntech, United States). The electrodes from carbon fiber were placed at the anode and cathode chamber with a cross-sectional area of $50 \mathrm{~cm}^{2}$ then were connected by an external circuit using copper wires. An additional 1,000 $\Omega$ external resistor was added.

The PEM Nafion $117^{\circledR}$ membrane was treated by preliminary treatments [29]. The Nafion membrane was boiled in $3 \% \mathrm{v} / \mathrm{v}$ hydrogen peroxide $\left(\mathrm{H}_{2} \mathrm{O}_{2}\right)$ solution to remove organic impurities, then was washed with distilled water 3 times. The next step the Nafion membrane was boiled in $1 \mathrm{M} \mathrm{H}_{2} \mathrm{SO}_{4}$ solution to remove inorganic or metal impurities and give acidic properties to the sulfonic side, and then was washed with distilled water 3 times again. Each treatment was done for $1 \mathrm{~h}$. The membrane was stored in distilled water before being used. The membrane was stuck in the chamber by a seal. The chamber was sterilized by spraying alcohol followed by sterilization using a UV light in laminar airflow for $45 \mathrm{~min}$. The carbon fiber electrodes were sterilized by spraying alcohol and burning on a bunsen burner.

The anode compartment was fulfilled by substrate solutions which the concentration and sterilization condition followed experimental design, buffer solution $\mathrm{pH} \pm 7$, and $5 \mathrm{~mL}$ of Staphylococcus saprophyticus ICBB 9554 that has cultured. The exoelectrogen bacteria, Staphylococcus saprophyticus ICBB 9554, was inoculated in $100 \mathrm{~mL}$ of thioglycolate broth media, by taking 1 loop culture stock. The inoculant were incubated about $8 \mathrm{~h}$ at ambient temperature until reach OD 0.5 . Whereas the cathode compartment was filled by $0.1 \mathrm{M} \mathrm{KMnO}_{4}$ and $0.1 \mathrm{M} \mathrm{KH}_{2} \mathrm{PO}_{4}$ that has been sterilized using an autoclave.

\section{Data measurement}

The treated rice straw was analyzed for fiber content including lignin, cellulose, and hemicellulose followed the procedure of AOAC (1998). The analysis consists of Neutral Detergent Fiber (NDF), Acid Detergent Fiber (ADF), cellulose, and lignin. The NDF and ADF were used to determine hemicellulose levels, which is the calculation of NDF minus ADF.

The MFC performance was monitored by measuring electric current parameters (I) and voltage (V) using a multimeter every $8 \mathrm{~h}$ during the incubation period. The magnitude between current and voltage was validated by the formula $\mathrm{I}=\mathrm{V} / \mathrm{R}$, where $\mathrm{R}$ was the resistance of an external resistor whose value was equal to $1,000 \Omega$. Then the power $(\mathrm{P})$ was calculated using the formula $\mathrm{P}=\mathrm{I} \times \mathrm{V}$. Power density was normalized by dividing the power value by the area of the anode [8].

The procedure of chemical oxygen demand measurement used closed reflux titrimetric method [30]. The aim of $\mathrm{pH}$ measurement was to determine the acidity or alkalinity of culture media (anolite) before and after incubation of the MFC. While the measurement of Eh was to determine the redox potential from media. Both $\mathrm{pH}$ and Eh were measured using a $\mathrm{pH}-\mathrm{Eh}$ meter. Coulombic efficiency was calculated using equation: 
$\eta=\mathrm{M} \int \mathrm{Idt} / \mathrm{bcvf} \times 100 \%$

where $b$ is the number of moles of electrons produced per mole of substrate ( 4 moles of $\mathrm{e}^{-} \mathrm{mol}^{-1}$ based on oxygen), $c(\mathrm{mg} / \mathrm{l})$ is total COD removal, $v$ is the anolite volume $(\mathrm{mL}), f$ is Faraday's constant $[96,485 \mathrm{C}$ $\left.(\mathrm{mol} \mathrm{e})^{-1}\right], I$ is electrical current, and $M$ is the relative molecular weight (32 $\mathrm{g} / \mathrm{mol}$ oxygen) [31].

\section{Analysis}

The experimental data on the performance of the MFC system include electrical voltage, electrical current, and power density, $\mathrm{pH}$ and Eh were analyzed descriptively while the parameters of COD removal efficiency and Coulombic efficiency were analyzed by ANOVA (Analysis of Variance) with a significance level of $\alpha=0.05$. If significantly different, it would be further tested with the Duncan test using SPSS 24 software.

\section{Results and discussion}

Fiber content

In general, plant biomass is lignocellulose contain of cellulose, hemicellulose, and lignin that is different percentage for different plants. The cellulose is encapsulated by lignin and hemicellulose that gives hydrophobic trait. The cellulose has a crystalline structure so plant biomass needs to deconstruct to become a simpler chemical structure before ready used by microbes in MFC [14]. The results of this study showed that treated rice straw gave a higher cellulose to be accessed by microbes thus the electricity generation also higher than rice straw without pretreatment. The highest percentage of cellulose content was in the microwave-assisted alkali pretreatment which was $29.36 \%$ and the lowest in the control or without pretreatment which was $18.28 \%$ (Table 1). The high levels of cellulose content in microwave-assisted alkali pretreatment due to destruction lignocellulose structure and cellulose released to be free. The low levels of cellulose content in Xanthomonas translucens ICBB 9762 inoculation pretreatment illustrates cellulose that is released from lignocellulose structure is only small amount then free cellulose was degraded by cellulolytic bacteria. Whereas the percentage of cellulose content in combination of the microwave-assisted alkali followed Xanthomonas translucens ICBB 9762 inoculation pretreatment is not too high because the high free cellulose by microwave was degraded by cellulolytic bacteria.

Table 1 Lignin, hemicellulose, and cellulose content resulting from each pretreatment.

\begin{tabular}{lccc}
\hline \multicolumn{1}{c}{ Pretreatment } & Hemicellulose (\%) & Cellulose (\%) & Lignin (\%) \\
\hline Microwave-assisted alkali and Xanthomonas translucens & 13.77 & 21.47 & 17.20 \\
ICBB 9762 inoculation & & 29.36 & 19.19 \\
Microwave-assisted alkali & 22.76 & 20.27 & 14.30 \\
Xanthomonas translucens ICBB 9762 inoculation & 13.52 & 18.28 & 10.87 \\
Without pretreatment & 14.89 & & \\
\hline
\end{tabular}

\section{MFC performance}

The main functionality of MFC is based on utilizing the available electrons (e) naturally and artificially introducing electrodes as intermediate/terminal electron acceptors. Substrate oxidation that catalyzed by microbes occurs at the biotic anode, whereas reduction occurs at the abiotic cathode. The oxidation process of organic matter produces protons and electrons. The protons cross the proton exchange membrane (PEM) and reach the cathode to generate a positive cathodic potential. The electrons remaining at the anode space generate a negative anodic potential. The difference between positive cathodic and negative anodic potential is considered the cell voltage, known as the electron motive force which acts as driving force for electron movement from the anode to the cathode. The maximum electrical energy output can be achieved by the lowest possible anode potential and the highest possible cathode potential [1].

Each type of pretreatments gave the same performance trend, namely high at the beginning of the incubation period, then decreased after $\pm 72 \mathrm{~h}$ and tended to be constant until the end of the incubation period. This is refer to another study the which produced power density from cellulose in an MFC using 2 
microbial cultures which were $C$. cellulolyticum as a degrading cellulose and G. sulfurreducens as an exoelectrogen bacteria that generate electricity [7].

The highest voltage, electricity, and power density in the MFC system achieved by combination of microwave-assisted alkali followed Xanthomonas translucens ICBB 9762 inoculation (A) on substrate concentration of $0.6 \%(\mathrm{w} / \mathrm{v})$ without sterilization and no Staphylococcus saprophyticus ICBB 9556 addition (A6NS(-)) i.e. $337.90 \mathrm{mV} ; 0.39 \mathrm{~mA}$; and $26.20 \mathrm{~mW} / \mathrm{m}^{2}$, respectively (Figures 1a, 2a and 3a). While, the rice straw without pretreatment (D) produces the lowest voltage, electricity, and power density value i.e. $74.07 \mathrm{mV}$; $0.07 \mathrm{~mA}$; and $1.02 \mathrm{~mW} / \mathrm{m}^{2}$, respectively (Figures 1d, 2d and 3d) on substrate concentration of $0.6 \%(\mathrm{w} / \mathrm{v})$ with sterilization and with Staphylococcus saprophyticus ICBB 9556 addition $(\mathrm{D} 6 \mathrm{~S}(+))$ code. It was seen that the highest voltage occurred at a high concentration of $0.6 \%$ $(\mathrm{w} / \mathrm{v})$ then after the pretreatment not carried out sterilization and not exoelectrogen bacteria addition

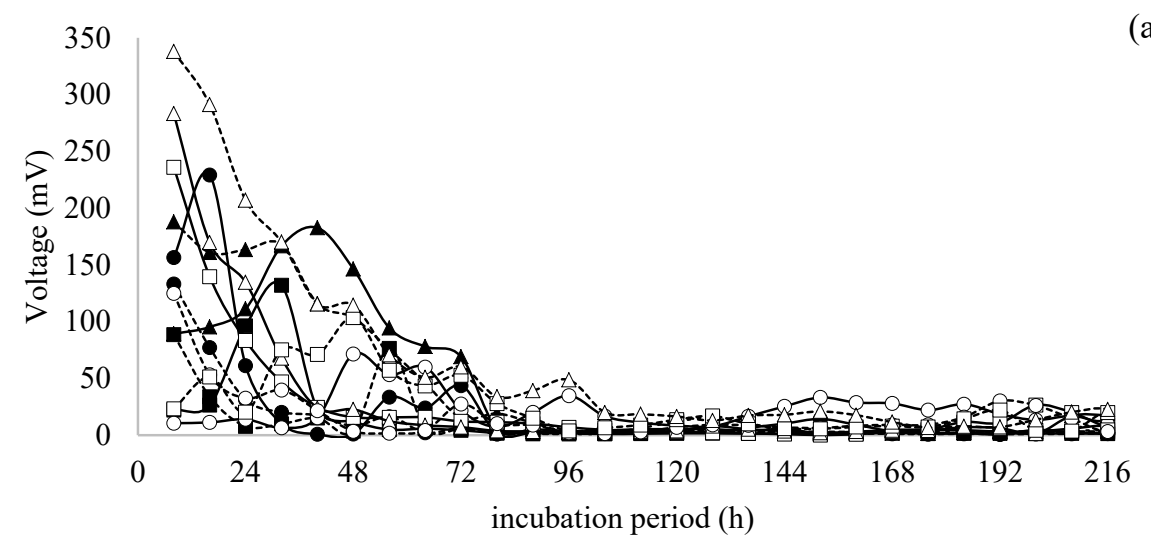

(a)

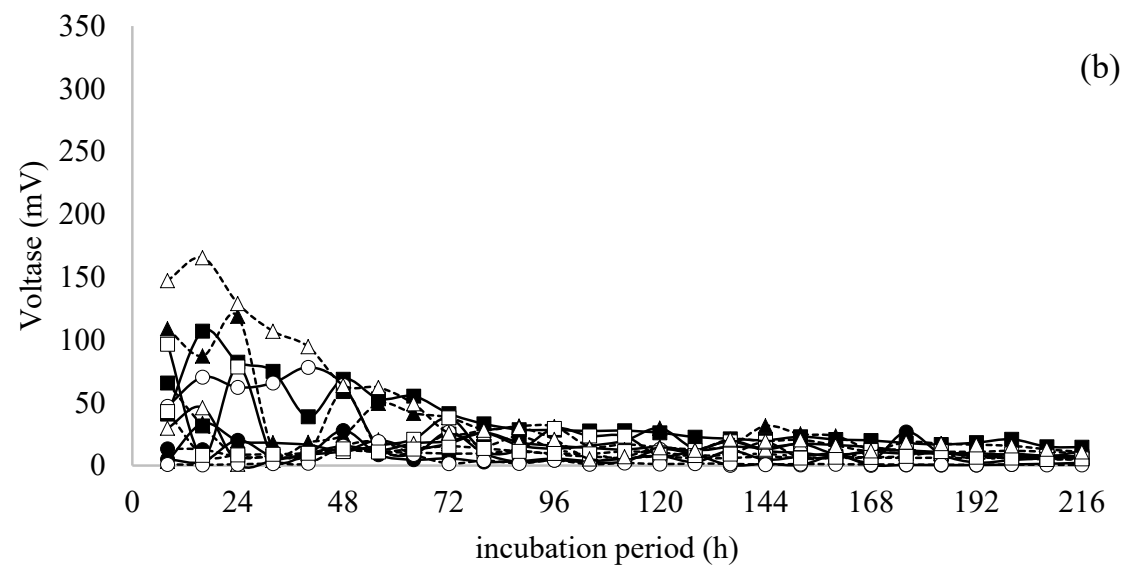




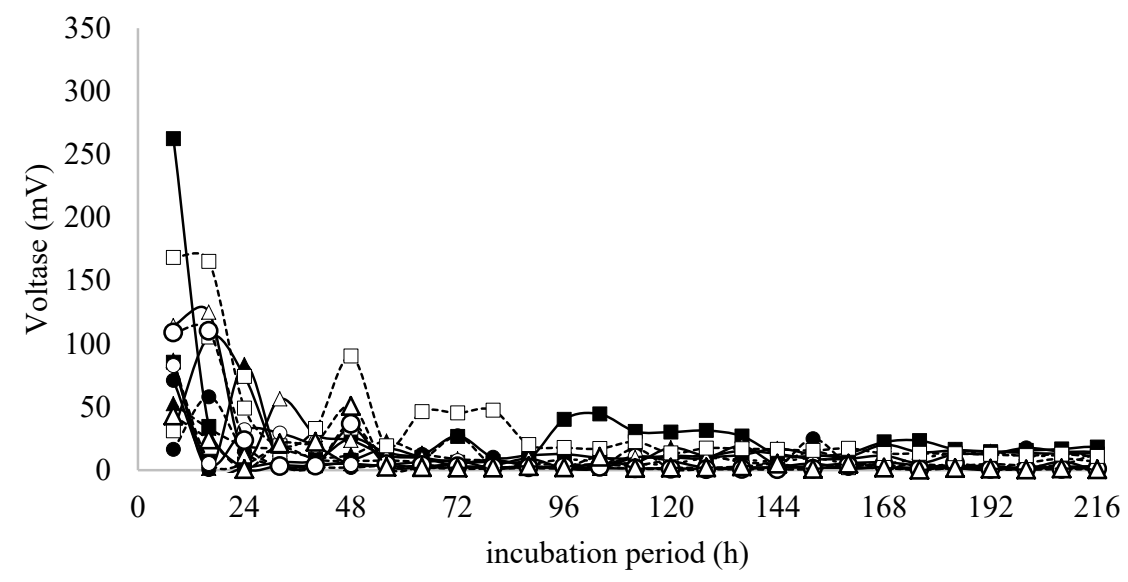

(c)

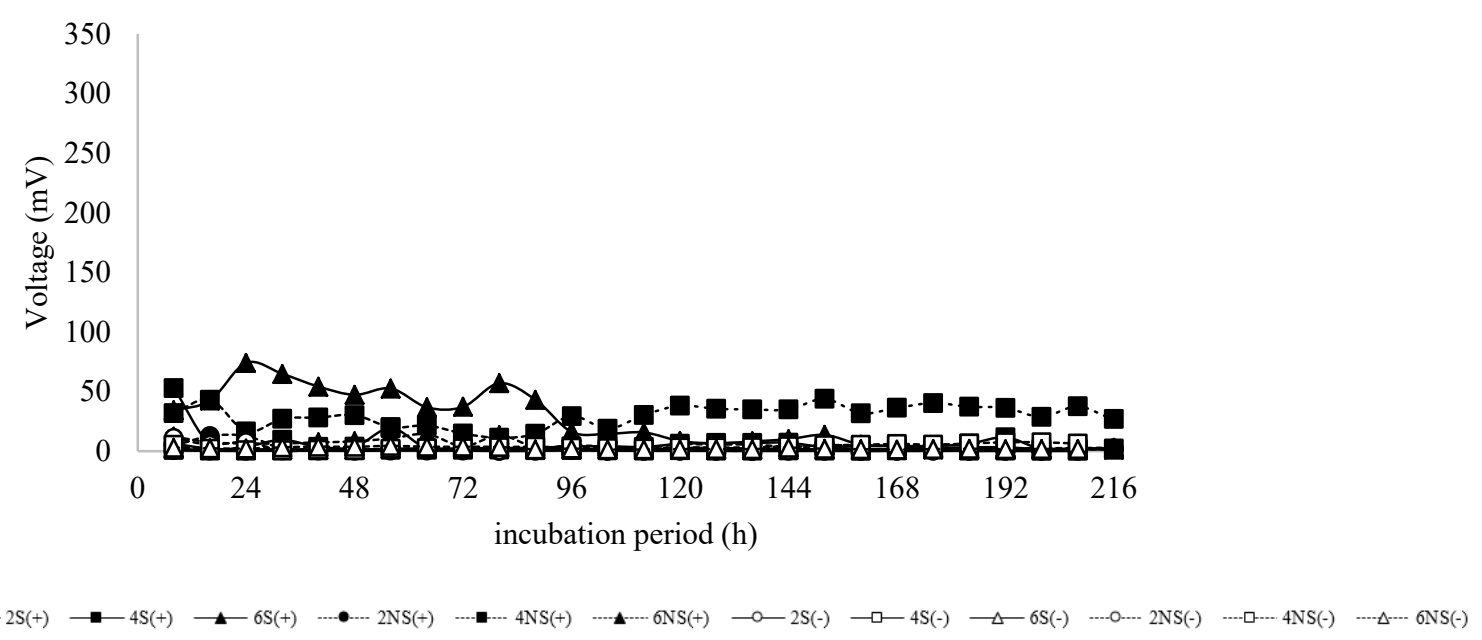

Figure 1 The electrical voltage of the MFC system fuelled treated rice straw substrates either the addition of excoelectrogen bacteria or not: (a) microwave-assisted alkali followed Xanthomonas translucens ICBB 9762 inoculation, (b) microwave-assisted alkali, (c) Xanthomonas translucens ICBB inoculation, and (d) without pretreatment.

Note

Substrate concentration $\quad: 2=0,2 \%(\mathrm{w} / \mathrm{v}) ; 4=0,4 \%(\mathrm{w} / \mathrm{v}) ; 6=0,6 \%(\mathrm{w} / \mathrm{v})$

Sterilization $\quad: \mathrm{S}=$ with sterilization; NS $=$ no sterilization

Addition of Staphylococcus saprophyticus ICBB 9554: $(+)=$ with addition; $(-)=$ no/without addition 


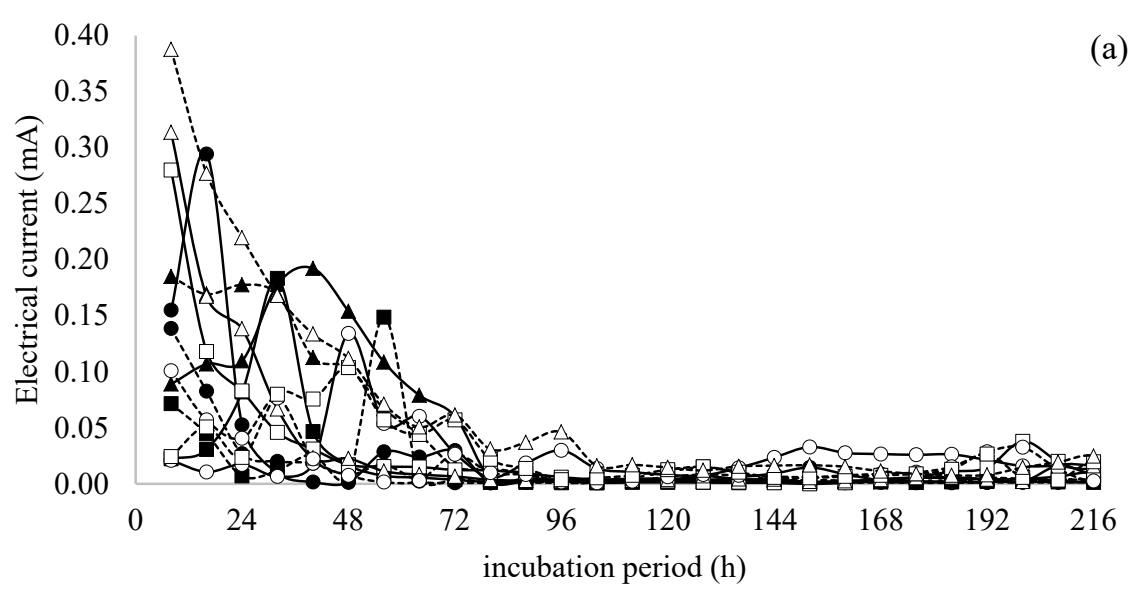

(a)
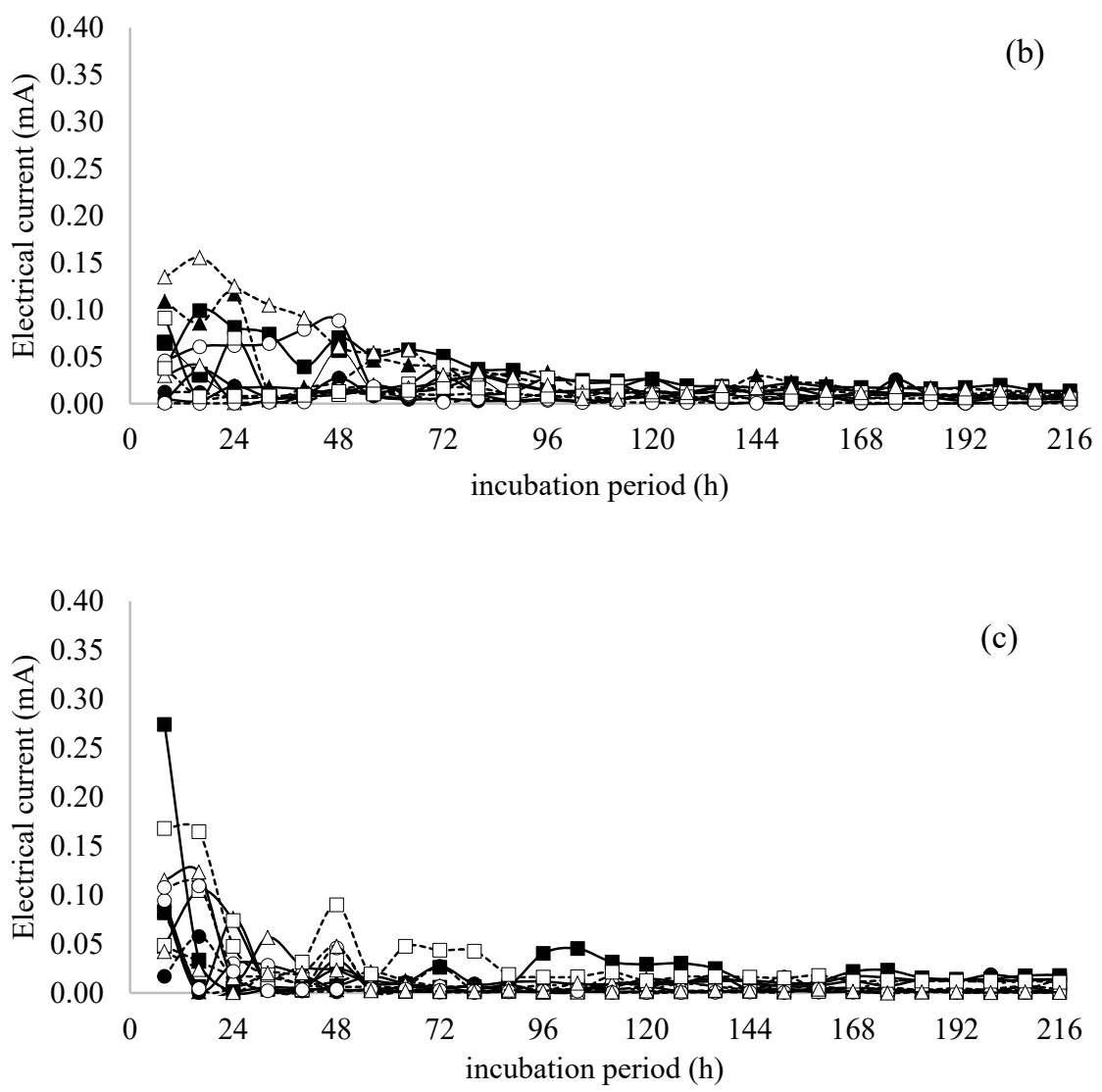


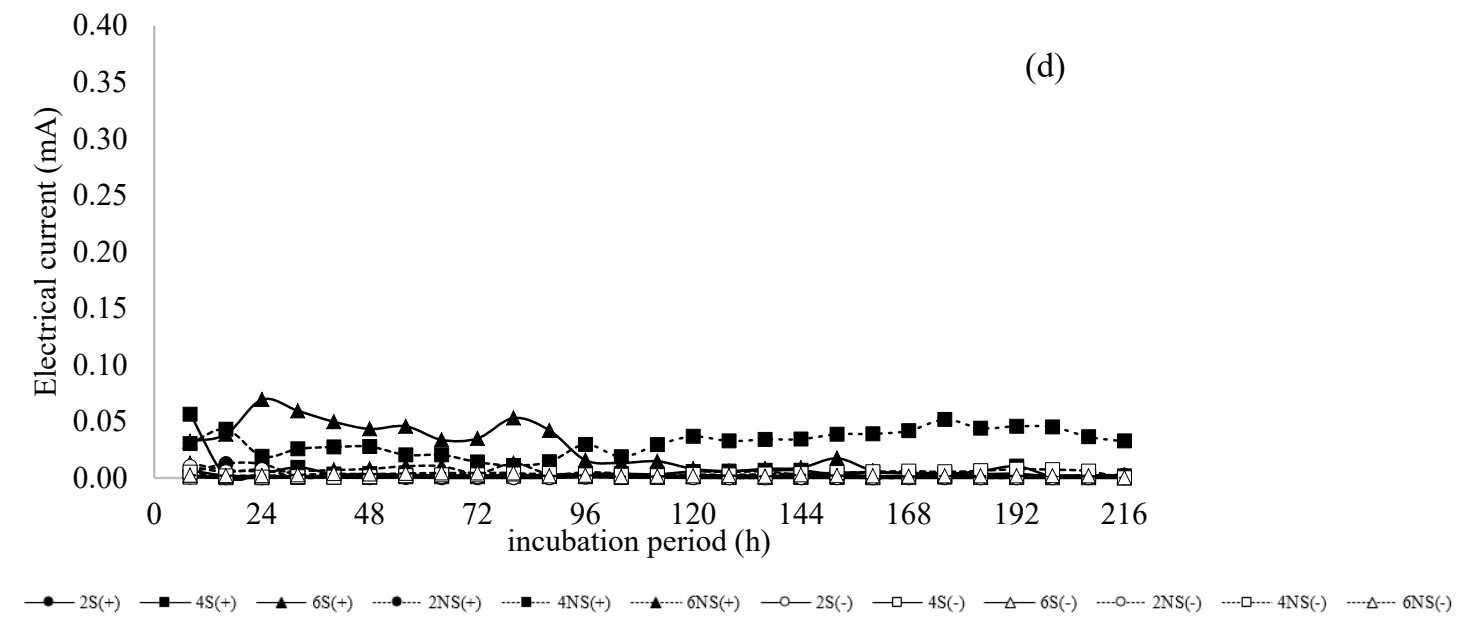

Figure 2 The electrical current of the MFC system fuelled treated rice straw substrates either the addition of excoelectrogen bacteria or not: (a) microwave-assisted alkali followed Xanthomonas translucens ICBB 9762 inoculation, (b) microwave-assisted alkali, (c) Xanthomonas translucens ICBB 9762 inoculation, and (d) without pretreatment.

Note

Substrate concentration $\quad: 2=0,2 \%(\mathrm{w} / \mathrm{v}) ; 4=0,4 \%(\mathrm{w} / \mathrm{v}) ; 6=0,6 \%(\mathrm{w} / \mathrm{v})$

Sterilization $\quad: \mathrm{S}=$ with sterilization; $\mathrm{NS}=$ no sterilization

Addition of Staphylococcus saprophyticus ICBB 9554: $(+)=$ with addition; $(-)=$ no/without addition

The highest performance was achieved by microwave-assisted alkali followed by Xanthomonas translucens ICBB 9762 inoculation pretreatment. Several studies have shown that microwave irradiation can alterate the structure of cellulose, break down the lignin and hemicellulose, and increase the enzymatic susceptibility of lignocellulosic material. When it is continued by biological pretreatment, enzymatic hydrolysis produces high reducing sugars because cellulase enzyme only catalyze the hydrolysis reaction not the process of sugar degradation [32].

The results showed that the higher substrate concentration will increase the MFC performance. The higher substrate concentration will increase electrical energy generation due to the higher concentration of nutrients or substrates will increase the physiological parameters of microbes that is stimulated by microbial metabolism. When the concentration continues to increase, peak point will be reached then substrate added will not increase physiological parameters. At that point, other environmental factors have reached the optimum point in supplying microbial metabolism or microbial cells have reached their own limits to grow [33].

The non-sterile conditions and the absence of exoelectrogen bacteria, Staphylococcus saprophyticus ICBB 9554, caused the higher voltage than sterilize substrates and presence of Staphylococcus saprophyticus $I C B B 9554$ due to the influence of indigenous microbes that may have the ability to transfer electrons. Electron production is higher in mix cultures compared to pure culture [34]. Mix culture is able to provide substrate that are more efficient and dense than pure culture. While pure culture has technical limitations that need to be ensured which were tighter growth conditions and only selective substrates can be used. Thus consortium can be selected if use a complex substrate. However, pure culture is useful in clarifying the mechanism of electron transfer at the microbiological level [35].

\section{COD removal efficiency}

This study showed there was a pretreatment group that COD efficiency value was positive but on the other hand there was a negative value (Table 2). A negative value on the COD removal efficiency indicated an increase in COD after incubation compared before incubation in MFC system. The pretreatments that showed negative value were combination of microwave-assisted alkali followed Xanthomonas translucens ICBB 9762 inoculation pretreatment and Xanthomonas translucens ICBB 9762 inoculation pretreatment only. The COD measurements were carried out on the solution whereas in this study the organic material used was not only hydrolysate but also rice straw solid powder. When the rice straw is incubated by cellulolytic bacteria, the water content is only around $200-300 \%$ and there take 
place degradation of organic matter by cellulolytic bacteria. This causes measurably low COD content. The dilution and incubation affect increase solubility of low molecular weight organic compounds due to the increase of cellulolytic bacterial access to the rice straw solid.

The value of COD removal efficiency ranged from $5.15-54.08 \%$ (Table 2). This value is relatively low compared to several studies such as [11] that utilize wheat straw hydrolyzate substrate that resulted COD removal up to $95 \%$ and study about MFC using paper recycling wastewater that contributed for COD removal up to $76 \%$ [36]. However, the COD removal efficiency from this study as low as cellulose substrate utilization that reported which reached efficiency of $38 \%$ and the study [37] that attain COD removal of $29.33 \%$.

Table 2 COD removal efficiency (\%) from rice straw anolite for each pretreatment.

\begin{tabular}{lcccc}
\hline Code & $\begin{array}{c}\text { Microwave-assisted alkali and } \\
\text { Xanthomonas translucens ICBB } \\
\text { inoculation 9762 pretreatment }\end{array}$ & $\begin{array}{c}\text { Microwave- } \\
\text { assisted alkali } \\
\text { pretreatment }\end{array}$ & $\begin{array}{c}\text { Xanthomonas translucens } \\
\text { ICBB inoculation 9762 } \\
\text { pretreatment }\end{array}$ & $\begin{array}{c}\text { Without } \\
\text { pretreatment }\end{array}$ \\
\hline $2 \mathrm{~S}(+)$ & $-168.30 \pm 14.52^{\mathrm{a}}$ & $44.87 \pm 4.18^{\mathrm{cde}}$ & $-85.19 \pm 0.00^{\mathrm{a}}$ & $49.55 \pm 0.71^{\mathrm{a}}$ \\
$2 \mathrm{~S}(-)$ & $-25.00 \pm 10.10^{\mathrm{cd}}$ & $7.61 \pm 10.76^{\mathrm{a}}$ & $-57.29 \pm 5.06^{\mathrm{a}}$ & $34.27 \pm 22.32^{\mathrm{a}}$ \\
$2 \mathrm{NS}(+)$ & $-28.26 \pm 6.76^{\mathrm{cd}}$ & $23.89 \pm 15.38^{\mathrm{abc}}$ & $-96.10 \pm 5.38^{\mathrm{a}}$ & $24.93 \pm 2.29^{\mathrm{a}}$ \\
$2 \mathrm{NS}(-)$ & $-133.91 \pm 4.92^{\mathrm{b}}$ & $30.39 \pm 21.54^{\mathrm{bcd}}$ & $-57.68 \pm 2.72^{\mathrm{a}}$ & $18.86 \pm 0.57^{\mathrm{a}}$ \\
$4 \mathrm{~S}(+)$ & $-34.88 \pm 3.29^{\mathrm{c}}$ & $23.73 \pm 1.46^{\mathrm{abc}}$ & $-63.16 \pm 4.48^{\mathrm{a}}$ & $34.20 \pm 1.36^{\mathrm{a}}$ \\
$4 \mathrm{~S}(-)$ & $-12.09 \pm 1.32^{\mathrm{de}}$ & $5.15 \pm 0.00^{\mathrm{a}}$ & $-58.39 \pm 40.73^{\mathrm{a}}$ & $35.16 \pm 1.82^{\mathrm{a}}$ \\
$4 \mathrm{NS}(+)$ & $-30.44 \pm 2.83^{\mathrm{c}}$ & $13.42 \pm 6.80^{\mathrm{ab}}$ & $-38.61 \pm 9.85^{\mathrm{a}}$ & $27.18 \pm 8.45^{\mathrm{a}}$ \\
$4 \mathrm{NS}(-)$ & $-23.33 \pm 0.94^{\mathrm{cd}}$ & $31.73 \pm 5.44^{\mathrm{bcd}}$ & $-27.76 \pm 25.18^{\mathrm{a}}$ & $35.69 \pm 1.80^{\mathrm{a}}$ \\
$6 \mathrm{~S}(+)$ & $-33.11 \pm 6.60^{\mathrm{c}}$ & $53.65 \pm 5.14^{\mathrm{e}}$ & $-9.58 \pm 1.09^{\mathrm{a}}$ & $47.53 \pm 1.47^{\mathrm{a}}$ \\
$6 \mathrm{~S}(-)$ & $-23.33 \pm 11.63^{\mathrm{cd}}$ & $48.18 \pm 2.57^{\mathrm{de}}$ & $-16.90 \pm 2.34^{\mathrm{a}}$ & $47.79 \pm 0.37^{\mathrm{a}}$ \\
$6 \mathrm{NS}(+)$ & $-3.49 \pm 1.82^{\mathrm{e}}$ & $50.52 \pm 3.60^{\mathrm{de}}$ & $-23.56 \pm 1.326^{\mathrm{a}}$ & $41.73 \pm 0.00^{\mathrm{a}}$ \\
$6 \mathrm{NS}(-)$ & $-5.87 \pm 2.59^{\mathrm{e}}$ & $34.18 \pm 3.61^{\mathrm{bcde}}$ & $-13.39 \pm 9.62^{\mathrm{a}}$ & $54.08 \pm 0.99^{\mathrm{a}}$ \\
\hline
\end{tabular}

Note: Values in a column which not sharing the same letter is significantly different from each other $(\mathrm{p}<0.05$; Duncan test)






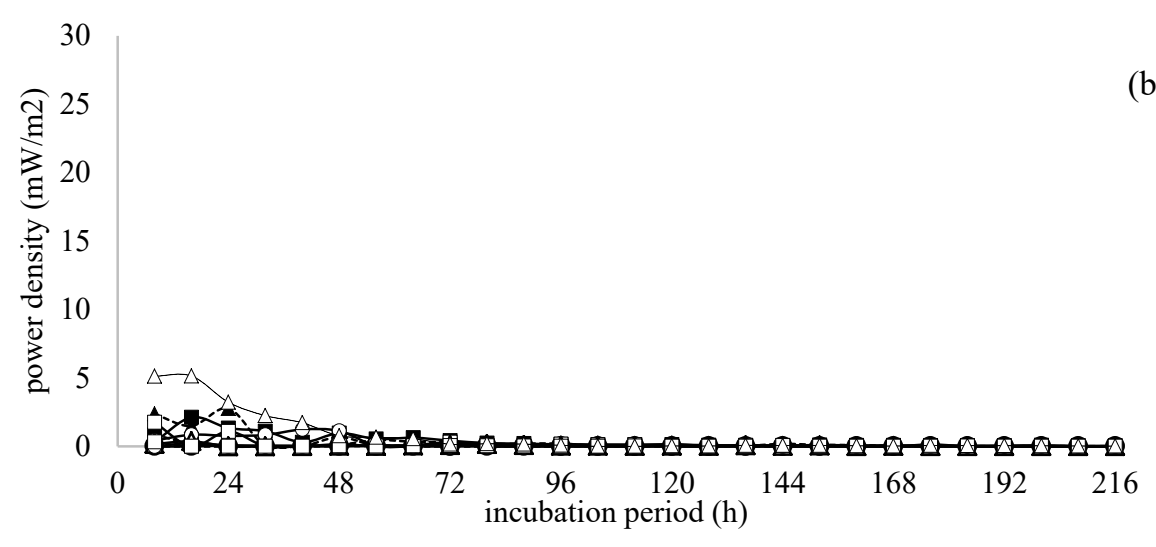

(b)
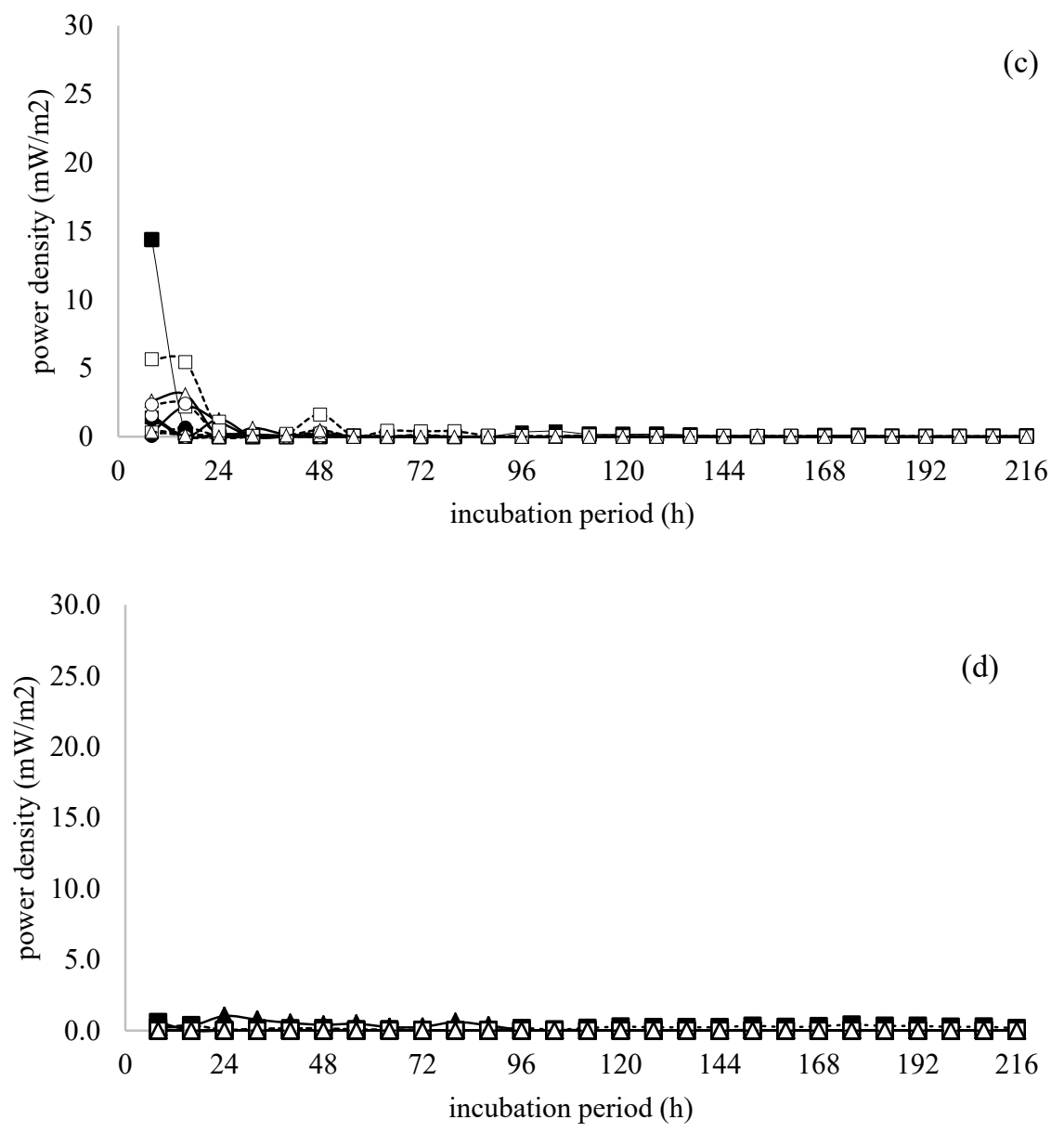

Figure 3 The power density of the MFC system fuelled treated rice straw substrates either the addition of excoelectrogen bacteria or not: (a) microwave-assisted alkali followed Xanthomonas translucens ICBB 9762 inoculation, (b) microwave-assisted alkali, (c) Xanthomonas translucens ICBB 9762 inoculation, and (d) without pretreatment.

Note

Substrate concentration $\quad: 2=0,2 \%(\mathrm{w} / \mathrm{v}) ; 4=0,4 \%(\mathrm{w} / \mathrm{v}) ; 6=0,6 \%(\mathrm{w} / \mathrm{v})$

Sterilization $\quad: \mathrm{S}=$ with sterilization; $\mathrm{NS}=$ no sterilization

Addition of Staphylococcus saprophyticus ICBB 9554: $(+)=$ with addition; $(-)=$ no/without addition 


\section{Coulombic efficiency}

The Coulombic efficiency needed COD parameters in its calculations. There were negative COD removal values thus there was also a negative value for Coulombic efficiency. Only microwave-assisted alkali and without pretreatment rice straw can be calculated to have efficiency. The Coulombic efficiency values ranged from $0.25-7.83 \%$ (Table 3). This value is relatively low compared to some studies that were mentioned in the COD removal efficiency [7,11,36,37] that reported Coulombic efficiency ranging for $9-17,16,47$, and $41.5 \%$ respectively. Those results appeared that some studies with higher COD removal provide lower Coulombic efficiency, on the contrary. This is refers to equation 3 where the Coulombic efficiency value is inversely proportional to COD removal.

The coulombic efficiency describes the efficiency of the total Coulombs actually transferred from the substrate by microbial metabolism to the electrodes. The Coulombic efficiency is diminished when there is an alternative electron acceptor other than electrodes by bacteria, either those present in the medium (or wastewater), or those diffusing through membrane such as oxygen. Other factors that reduce Coulombic efficiency are competitive processes and bacterial growth. Bacteria unable to utilize electrodes as electron acceptors tend to use substrates for fermentation. It has been observed that the fermentative pattern diminish through time during enrichment of the microbial consortium in the MFC [5].

Table 3 Coulombic efficiency (\%) from rice straw anolite for each pretreatment.

\begin{tabular}{lcccc}
\hline Code & $\begin{array}{c}\text { Microwave-assisted alkali and } \\
\text { Xanthomonas translucens ICBB } \\
\text { inoculation 9762 pretreatment }\end{array}$ & $\begin{array}{c}\text { Microwave- } \\
\text { assisted alkali } \\
\text { pretreatment }\end{array}$ & $\begin{array}{c}\text { Xanthomonas translucens } \\
\text { ICBB inoculation 9762 } \\
\text { pretreatment }\end{array}$ & $\begin{array}{c}\text { Without } \\
\text { pretreatment }\end{array}$ \\
\hline $2 \mathrm{~S}(+)$ & $-0.42 \pm 0.04^{\mathrm{a}}$ & $2.96 \pm 0.28^{\mathrm{a}}$ & $-1.03 \pm 0.00^{\mathrm{a}}$ & $0.44 \pm 0.01^{\mathrm{a}}$ \\
$2 \mathrm{~S}(-)$ & $-6.01 \pm 2.43^{\mathrm{a}}$ & $1.63 \pm 2.30^{\mathrm{a}}$ & $-1.05 \pm 0.09^{\mathrm{a}}$ & $0.54 \pm 0.35^{\mathrm{a}}$ \\
$2 \mathrm{NS}(+)$ & $-2.20 \pm 0.53^{\mathrm{a}}$ & $5.79 \pm 3.73^{\mathrm{a}}$ & $-0.61 \pm 0.03^{\mathrm{a}}$ & $2.52 \pm 0.23^{\mathrm{b}}$ \\
$2 \mathrm{NS}(-)$ & $-0.76 \pm 0.03^{\mathrm{a}}$ & $3.82 \pm 2.71^{\mathrm{a}}$ & $-1.32 \pm 0.06^{\mathrm{a}}$ & $0.71 \pm 0.02^{\mathrm{a}}$ \\
$4 \mathrm{~S}(+)$ & $-1.37 \pm 0.13^{\mathrm{a}}$ & $2.07 \pm 0.03^{\mathrm{a}}$ & $-2.17 \pm 0.15^{\mathrm{a}}$ & $1.51 \pm 0.06^{\mathrm{ab}}$ \\
$4 \mathrm{~S}(-)$ & $-6.18 \pm 0.67^{\mathrm{a}}$ & $0.25 \pm 0.00^{\mathrm{a}}$ & $-1.45 \pm 1.01^{\mathrm{a}}$ & $1.19 \pm 0.06^{\mathrm{ab}}$ \\
$4 \mathrm{NS}(+)$ & $-1.60 \pm 0.15^{\mathrm{a}}$ & $1.42 \pm 0.13^{\mathrm{a}}$ & $-1.32 \pm 0.34^{\mathrm{a}}$ & $7.83 \pm 2.43^{\mathrm{d}}$ \\
$4 \mathrm{NS}(-)$ & $-3.32 \pm 0.13^{\mathrm{a}}$ & $6.60 \pm 1.13^{\mathrm{a}}$ & $-6.67 \pm 6.05^{\mathrm{a}}$ & $1.63 \pm 0.08^{\mathrm{ab}}$ \\
$6 \mathrm{~S}(+)$ & $-4.03 \pm 0.80^{\mathrm{a}}$ & $2.17 \pm 0.19^{\mathrm{a}}$ & $-6.12 \pm 0.70^{\mathrm{a}}$ & $5.57 \pm 0.17^{\mathrm{c}}$ \\
$6 \mathrm{~S}(-)$ & $-3.81 \pm 1.90^{\mathrm{a}}$ & $2.12 \pm 0.10^{\mathrm{a}}$ & $-3.32 \pm 0.46^{\mathrm{a}}$ & $0.59 \pm 0.00^{\mathrm{a}}$ \\
$6 \mathrm{NS}(+)$ & $-23.89 \pm 4.41^{\mathrm{a}}$ & $3.41 \pm 0.24^{\mathrm{a}}$ & $-1.66 \pm 0.09^{\mathrm{a}}$ & $1.79 \pm 0.00^{\mathrm{ab}}$ \\
$6 \mathrm{NS}(-)$ & $-24.18 \pm 5.67^{\mathrm{a}}$ & $5.05 \pm 0.53^{\mathrm{a}}$ & $-2.07 \pm 1.59^{\mathrm{a}}$ & $0.37 \pm 0.01^{\mathrm{a}}$ \\
\hline
\end{tabular}

Note: Values in a column which not sharing the same letter is significantly different from each other $(\mathrm{p}<0.05$; Duncan test)

\section{Measurement of $\mathrm{pH}$ and $\mathrm{Eh}$}

Both before and after MFC system incubation showed that the $\mathrm{pH}$ was around neutral to acidic conditions at a maximum of 7 (Figure 4). Acidic conditions in the environment occur due to microbial metabolic activity that produces organic acids [30] where there was a decrease in $\mathrm{pH}$ during incubation in the MFC system. However, in this study the initial conditions before incubation showed a lower $\mathrm{pH}$ than after incubation or incubation caused $\mathrm{pH}$ increase. The fact that the incubation of the MFC system increase $\mathrm{pH}$ was possible because the anolite was added buffer solution and there was a transfer of protons across the membrane from the anode space to the cathode space. Only the MFC system with rice straw that was treated by Xanthomonas translucens ICBB 9762 inoculation has a higher $\mathrm{pH}$ than others. The $\mathrm{pH}$ value of Xanthomonas translucens ICBB 9762 inoculation pretreatment was around 6 and up to 7. While the $\mathrm{pH}$ after incubation of rice straw from the other pretreatment showed a maximum value of 6 and the others were below of 6 .

The Eh value of MFC system in this research was generally almost reached anoxic condition. The order of the highest Eh was treated rice straw by microwave-assisted alkali followed Xanthomonas translucens ICBB 9762 inoculation pretreatment, then Xanthomonas translucens ICBB 9762 inoculation pretreatment, then microwave-assisted alkali pretreatment (A), and the lowest was untreated rice straw (Figure 5). In Xanthomonas translucens ICBB 9762 inoculation pretreatment showed a negative Eh value. Those treatments were the substrate concentration of $0.4 \%(\mathrm{w} / \mathrm{v})$ without sterilization but with 
Staphylococcus saprophyticus ICBB 9556 addition $(\mathrm{C} 4 \mathrm{NS}(+))$ and the substrate concentration of $0.6 \%$ $(\mathrm{w} / \mathrm{v})$ without sterilization but with Staphylococcus saprophyticus ICBB 9556 addition (C6NS(+)).
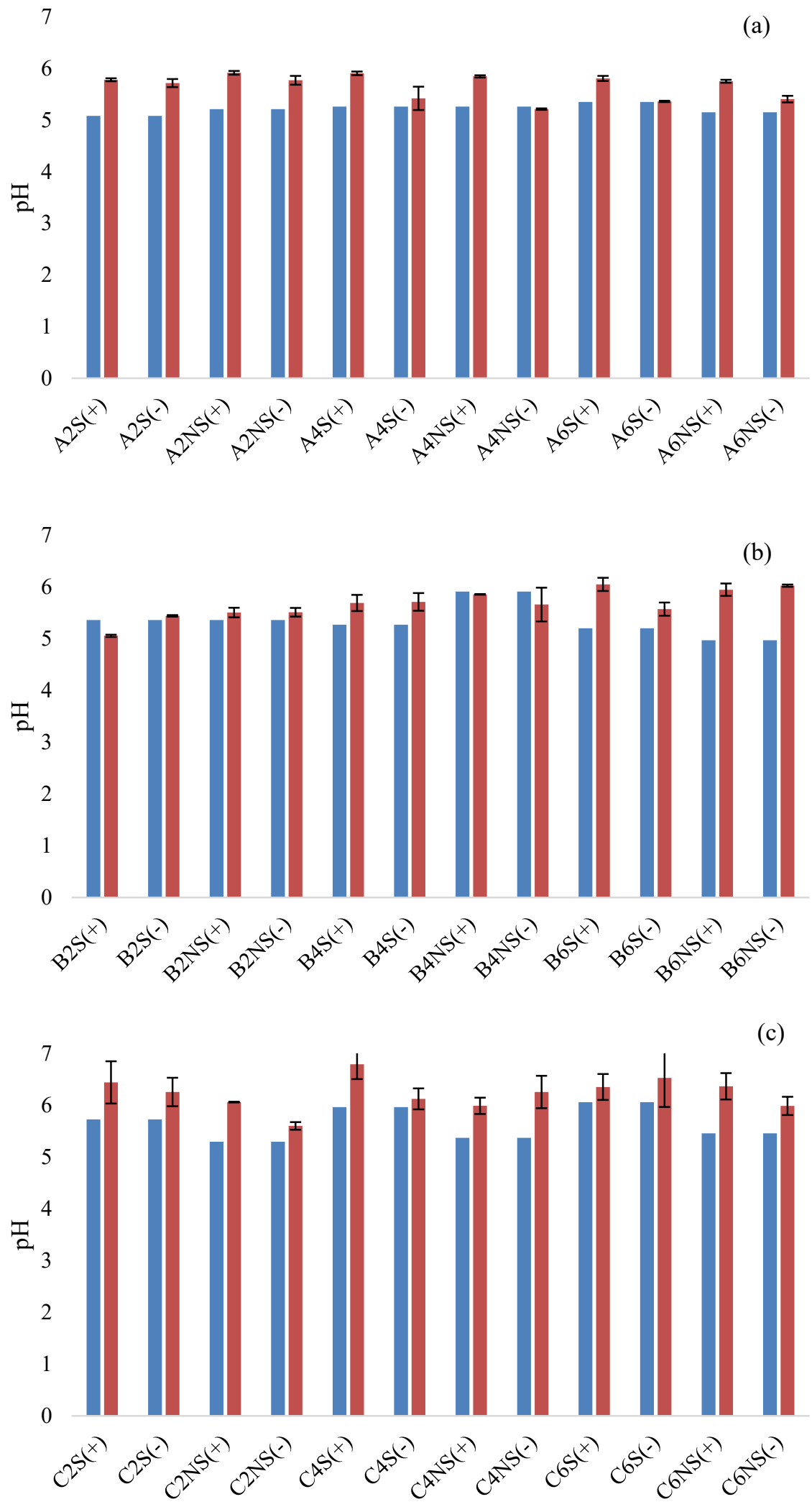


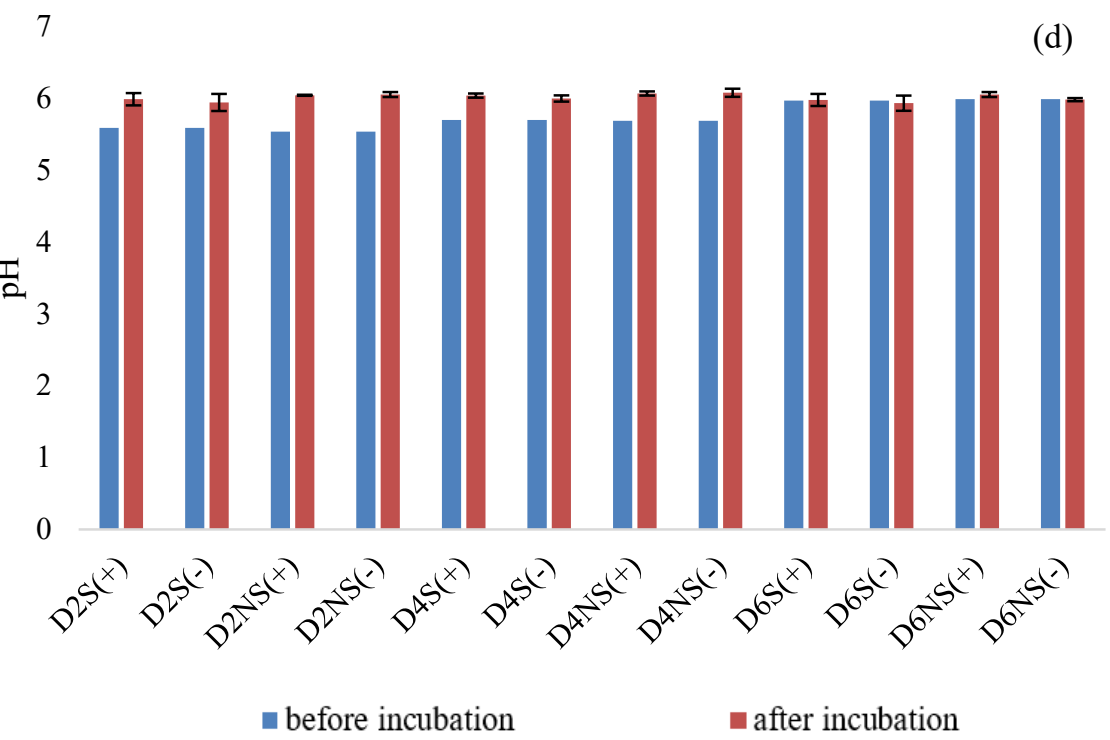

Figure 4 The anolite $\mathrm{pH}$ before and after incubation in the MFC system either the addition of excoelectrogen bacteria or not for (a) microwave-assisted alkali followed Xanthomonas translucens ICBB 9762 inoculation, (b) microwave-assisted alkali, (c) Xanthomonas translucens ICBB 9762 inoculation, and (d) without pretreatment.

Note

Substrate concentration $\quad: 2=0,2 \%(\mathrm{w} / \mathrm{v}) ; 4=0,4 \%(\mathrm{w} / \mathrm{v}) ; 6=0,6 \%(\mathrm{w} / \mathrm{v})$

Sterilization $\quad: \mathrm{S}=$ with sterilization; $\mathrm{NS}=$ no sterilization

Addition of Staphylococcus saprophyticus ICBB 9554: $(+)=$ with addition; $(-)=$ no/without addition

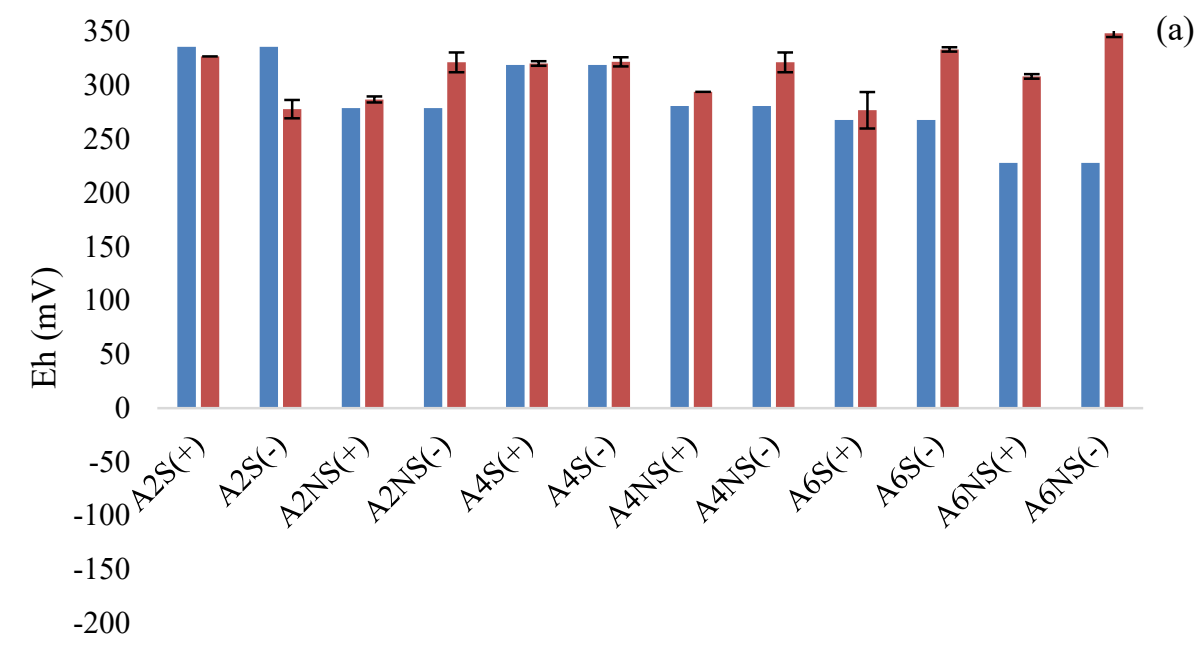



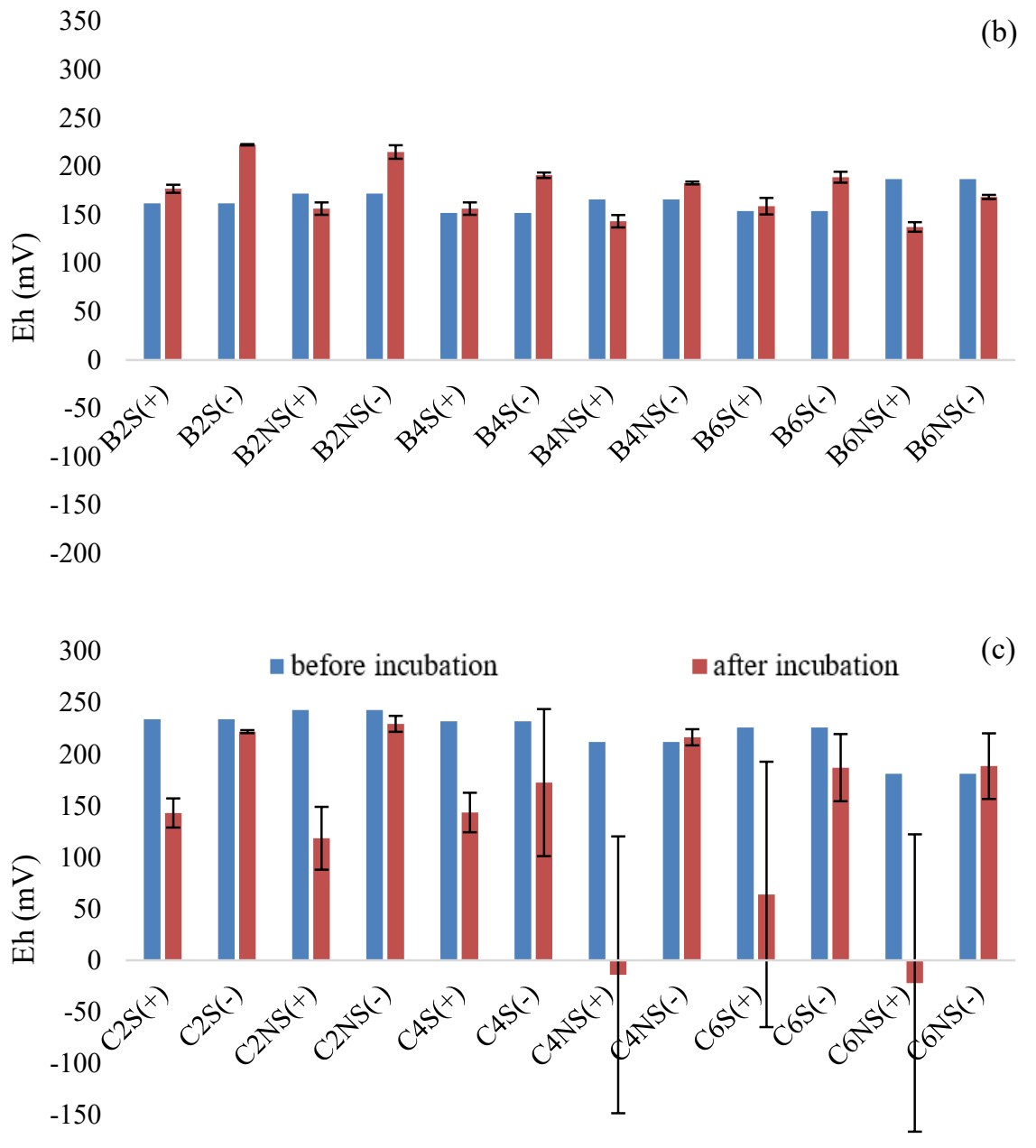

$-200$

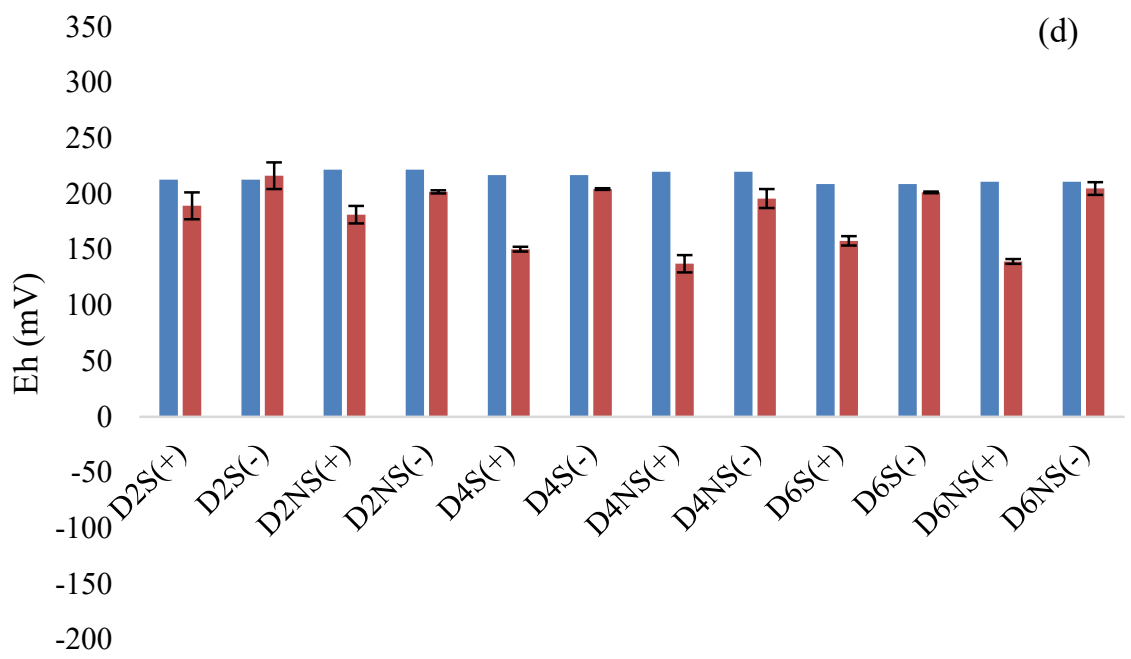

Figure 6 The anolite Eh before and after incubation in the MFC system either the addition of excoelectrogen bacteria or not for (a) microwave-assisted alkali followed Xanthomonas translucens ICBB 9762 inoculation, (b) microwave-assisted alkali, (c) Xanthomonas translucens ICBB 9762 inoculation, and (d) without pretreatment. 
Note

Substrate concentration $\quad: 2=0,2 \%(\mathrm{w} / \mathrm{v}) ; 4=0,4 \%(\mathrm{w} / \mathrm{v}) ; 6=0,6 \%(\mathrm{w} / \mathrm{v})$

Sterilization $\quad: \mathrm{S}=$ with sterilization; $\mathrm{NS}=$ no sterilization

Addition of Staphylococcus saprophyticus ICBB 9554: $(+)=$ with addition; $(-)=$ no/without addition

\section{Conclusions}

Rice straw is an agricultural residue with an abundant amount on earth [39]. Rice straw has the potential to be an organic substrate in the MFC system. However, because rice straw is a complex substrate, it requires a degradation process in order to cellulose encapsulated by lignin can be released. In this study, rice straw was successfully degraded by microwave-assisted alkali and Xanthomonas translucens ICBB 9762 inoculation pretreatment which the highest cellulose yield is $29.36 \%$. Treated rice straw is fuelled for MFC substrate and produces better performance than rice straw without pretreatment. The best MFC performance comes from rice straw which is treated by microwave-assisted alkali followed Xanthomonas translucens ICBB 9762 inoculation that reach the highest electrical voltage, electrical current, and power density of $337.90 \mathrm{mV}, 0.39 \mathrm{~mA}$, and $26.20 \mathrm{~mW} / \mathrm{m}^{2}$ respectively. There was increase and decrease for COD removal efficiency and Coulombic efficiency which ranged of $5.15-54.08 \%$ and $0.25-7.83 \%$ respectively. The $\mathrm{pH}$ of MFC system in this research was around neutral to acidic conditions at a maximum of 7 and the Eh value was generally almost reached anoxic condition. This research suggest to develop the other pretreatment methods that can contribute a higher performance for electricity production from lignocellulose in MFC. Furthermore, it is necessary to carry out more studies related to analysis or calculations parameters when using solid substrates in the MFC system.

\section{Acknowledgements}

We would like to thank to Ministry of Research and Technology of the Republic of Indonesia through the PMDSU (Program Mahasiswa Menuju Doktor untuk Sarjana Unggul) scholarship for providing the funding for this research. We also thank to Biology Laboratory of Soil Science and Land Resource Department of IPB University. Which is contribute to us for place and some equipment.

\section{References}

[1] SV Mohan, G Velvizhi, JA Modestra and S. Srikanth. Microbial fuel cell: Critical factors regulating bio-catalyzed electrochemical process and recent advancements. Renew. Sustain. Energ. Rev. 2014; 40, 779-97.

[2] V Chaturvedi and P Verma. Microbial fuel cell: A green approach for the utilization of waste for the generation of bioelectricity. Bioresour. Bioprocess. 2016; 3, 1-14.

[3] W Li, X Chen, L Xie, Z Liu and X Xiong. Bioelectrochemical systems for groundwater remediation: The development trend and research front revealed by bibliometric analysis. Water (Switzerland) 2019; 11, 1532.

[4] BE Logan. Exoelectrogenic bacteria that power microbial fuel cells. Nat. Rev. Microbiol. 2009; 7, 375-81.

[5] BE Logan, B Hamelers, R Rozendal, U Shroder, J Keller, S Freguia, P Aelterman, W Verstraete and K Rabaey. Critical review microbial fuel cells: Methodology and technology. Environ. Sci. Technol. 2006; 40, 5181-92.

[6] D Pant, GV Bogaert, L Diels and K Vanbroekhoven. A review of the substrates used in microbial fuel cells (MFCs) for sustainable energy production. Bioresour. Technol. 2010; 101, 1533-43.

[7] Z Ren, TE Ward and JM Regan. Electricity production from cellulose in a microbial fuel cell using a defined binary culture. Environ. Sci. Technol. 2007; 41, 4781-6.

[8] F Rezaei, D Xing, R Wagner, JM Regan, TL Richard and BE Logan. Simultaneous cellulose degradation and electricity production by Enterobacter cloacae in a microbial fuel cell. Appl. Environ. Microbiol. 2020; 75, 3673-8.

[9] Y Zhang, B Min, L Huang and I Angelidaki. Generation of electricity and analysis of microbial communities in wheat straw biomass-powered microbial fuel cells. Appl. Environ. Microbiol. 2020; 75, 3389-95.

[10] SHA Hassan, SMFG El-Rab, M Rahimnejad, M Ghasemi, JH Joo, Y Sik-Ok, IS Kim and SE Oh. Electricity generation from rice straw using a microbial fuel cell. Int. J. Hydrogen Energ. 2014; 39, 9490-6. 
[11] A Thygesen, FW Poulsen, I Angelidaki, B Min and AB Thomsen. Electricity generation by microbial fuel cells fuelled with wheat straw hydrolysate. Biomass Bioenerg. 2011; 35, 4732-9.

[12] M Pal and RK Sharma. Biomass and Bioenergy Development of wheat straw based catholyte for power generation in microbial fuel cell. Biomass Bioenerg. 2020; 138, 105591.

[13] TS Song, S Hou, J Zhang, H Wang and J Xie. Production of electricity from rice straw with different pretreatment methods using a sediment microbial fuel cell. Int. J. Electrochem. Sci. 2018; 13, 461-71.

[14] JC Liao, L Mi, S Pontrelli and S Luo. Fuelling the future: Microbial engineering for the production of sustainable biofuels. Nat. Rev. Microbiol. 2016; 14, 288-304.

[15] M Dashtban, H Schraft and W Qin. Fungal bioconversion of lignocellulosic residues: Opportunities \& perspectives. Int. J. Biol. Sci. 2009; 5, 578-95.

[16] GD Saratale, RG Saratale, S Varjani, SK Cho, GS Ghodake, A Kadam, SI Mulla, RN Bharagava, DS Kim and HS Shin. Development of ultrasound aided chemical pretreatment methods to enrich sacchari fi cation of wheat waste biomass for polyhydroxybutyrate production and its characterization. Ind. Crop. Prod. 2020; 150, 112425.

[17] RM Korai, C Wachemo, L Yue, M Jaffar, Z Li, M Shahbaz, H Yuan and X Li . Effect of ultrasonic application during $\mathrm{KOH}$ pretreatment and anaerobic process on digestion performance of wheat straw. RSC Dav. 2020; 10, 9290-8.

[18] TA Shah and R Ullah. Pretreatment of wheat straw with ligninolytic fungi for increased biogas productivity. Int. J. Environ. Sci. Technol. 2019; 16, 7497-508.

[19] T Krithika, R Kavitha, M Dinesh and J Angayarkanni. Assessment of ligninolytic bacterial consortium for the degradation of azo dye with electricity generation in a dual-chambered microbial fuel cell. Environ. Challenges 2021; 4, 100093.

[20] J Novakovic, N Kontogianni, EM Barampouti, S Mai, K Moustakas, D Malamis and M Loizidou. Towards upscaling the valorization of wheat straw residues: Alkaline pretreatment using sodium hydroxide, enzymatic hydrolysis and biogas production. Environ. Sci. Pollut. Res. 2020; 28, 2448698.

[21] M Wu, H Liu and C Yang. Effects of Pretreatment Methods of Wheat Straw on Adsorption of Cd (II) from Waterlogged Paddy Soil. Int. J. Environ. Res. Publ. Health. 2019; 16, 205.

[22] D Mikulski and G Klosowski. Microwave-assisted dilute acid pretreatment in bioethanol production from wheat and rye stillages. Biomass Bioenerg. 2020, 136, 105528.

[23] P Puligundla, SE Oh and C Mok. Microwave-assisted pretreatment technologies for the conversion of lignocellulosic biomass to sugars and ethanol: A review. Carbon Lett. 2016; 17, 1-10.

[24] R López-Mondéjar, D Zühlke, D Becher, K Riedel and P Baldrian. Cellulose and hemicellulose decomposition by forest soil bacteria proceeds by the action of structurally variable enzymatic systems. Sci. Rep. 2016; 6, 25279.

[25] F Rezaei, TL Richard and BE Logan. Enzymatic hydrolysis of cellulose coupled with electricity generation in a microbial fuel cell. Biotechnol. Bioeng. 2008; 101, 1163-9.

[26] YL Liang, Z Zhang, M Wu, Y Wu and JX Feng. Isolation, screening, and identification of cellulolytic bacteria from natural reserves in the subtropical region of China and optimization of cellulase production by Paenibacillus terrae ME27-1. Biomed Res. Int. 2014; 1, 512497.

[27] NS Khoirunnisa, S Anwar and DA Santosa. Isolation and selection of cellulolytic bacteria from rice straw for consortium of microbial fuel cell. Biodiversitas J. Biol. Divers. 2020; 21, 1686-96.

[28] MF Robitoh. Kombinasi Iradiasi Gelombang Mikro dan Fermentasi Ekstraktif Guna Optimasi Produksi Bioetanol dari Jerami Padi. In: Proceeding of the Peran Ilmu Kimia dalam Pengembangan Industri Kimia yang Ramah Lingkungan, Yogyakarta, Indonesia. 2015.

[29] L Mazzapioda, S Panero and MA Navarra. Polymer electrolyte membranes based on Nafion and a superacidic inorganic additive for fuel cell applications. Polymers 2019; 1, 914.

[30] SH Jenkins. Standard Methods for the Examination of Water and Wastewater. Water Res. 1982; 16, 1495- 6.

[31] RN Krishnaraj, S Berchmans and P Pal. The three-compartment microbial fuel cell: A new sustainable approach to bioelectricity generation from lignocellulosic biomass. Cellulose 2015; 22 , 655-62.

[32] MA Jablonska, MK Rybarczyk and M Lieder. Electricity generation from rapeseed straw hydrolysates using microbial fuel cells. Bioresource Technol. 2016; 208, 117-22.

[33] VH Edwards. The influence of high substrate concentrations on microbial kinetics. Biotechnol. Bioeng. 1970; 12, 679-712.

[34] PP Włodarczyk and B Włodarczyk. Wastewater treatment and electricity production in a microbial 
fuel cell with cu-B alloy as the cathode catalyst. Catalysts 2019; 9, 572.

[35] Y Cao, H Mu, W Liu, R Zhang, J Guo, Mo Xian and H Liu. Electricigens in the anode of microbial fuel cells: Pure cultures versus mixed communities. Microb. Cell Fact. 2019; 18, 39.

[36] L Huang and BE Logan. Electricity generation and treatment of paper recycling wastewater using a microbial fuel cell. Appl. Microbiol. Biotechnol. 2008; 80, 349-55.

[37] SHA Hassan, YS Kim and SE Oh. Power generation from cellulose using mixed and pure cultures of cellulose-degrading bacteria in a microbial fuel cell. Enzyme Microb. Technol. 2012; 51, 269-73.

[38] MPD Prasad, V Sridevi, PK Lakshmi and A Swathi. Treatment of Pharmaceutical Industrial Effluent By Microbial Fuel Cell (MFC). IJIRST-Int. J. Innov. Res. Sci. Technol. 2015; 2, $241-7$.

[39] S Pinzi and MP Dorado. 4 - Vegetable-based feedstocks for biofuels production. In: R Luque, J Campelo and J Clark (Eds.). Handbook of Biofuels Production. $1^{\text {st }}$ ed. Woodhead Publishing, Sawston, United Kingdom, 2011, p. 61-94. 